\title{
ESP TEACHING IN CONTEMPORARY MEDICAL EDUCATION IN BRAZIL
}

\author{
Athany Gutierres $^{1^{*}}$ \\ Ivana Loraine Lindemann ${ }^{2 *}$ \\ Cláudia Menoncini ${ }^{* * * *}$ \\ ${ }^{3}$ Universidade Federal da Fronteira Sul, Passo Fundo, RS, Brasil
}

\begin{abstract}
The early 2000s have witnessed significant changes in medical education in Brazil, especially because of the creation of the More Doctors Program (Programa Mais Médicos) in 2013 and the publication of the resolution that establishes the National Curricular Guidelines for Medicine undergraduate courses in 2014. The latter focuses on a human, critical and socially responsible education, which comprehends the development of the proficiency in a foreign language, preferably a lingua franca. The objectives of this paper are (i) to map the inclusion of foreign languages, particularly English, in Political Pedagogical Projects (PPPs) of public medical schools between the years 2013-2019; and (ii) to present a methodological proposal to the teaching of ESP in medical schools, according to the National Curricular Guidelines (Brasil, 2014). Online bibliographical research was carried out and data were collected from the e-MEC system and the PPPs. Descriptive statistics have shown that $65.1 \%$ of Medicine undergraduate courses $(n=28)$ include the proficiency of a foreign language in their PPPs, being that language English in 35.7\% and any other language in $64.3 \%$; $34.9 \%$ of the institutions do not incorporate any foreign language at all. Although the majority of medical schools seem to be conforming with the National Curricular Guidelines, there might be still a gap between targeted English language practices and their association to health education and the promotion of healthcare actions. Key-words: foreign languages; lingua franca; English for Specific Purposes (ESP); National Curricular Guidelines; medical education.
\end{abstract}

\footnotetext{
"Doutora em Letras pela Universidade Federal do Rio Grande do Sul (UFRGS). Coordenadora do Núcleo de Ensino de Línguas e docente do Curso de Graduação em Medicina da Universidade Federal da Fronteira Sul (UFFS) - Campus Passo Fundo. E-mail: athany.gutierres@uffs.edu.br. ORCID: orcid.org/0000-0003-3625-4240.

" Doutora em Ciências da Saúde pela Universidade Federal do Rio Grande (FURG). Docente do Curso de Graduação em Medicina da Universidade Federal da Fronteira Sul (UFFS) - Campus Passo Fundo. E-mail: ivana.lindemann@uffs.edu.br. ORCID: orcid.org/0000-0002-6222-9746.

${ }^{* * *}$ Acadêmica da III fase do Curso de Graduação em Medicina da Universidade Federal da Fronteira Sul (UFFS) - Campus Passo Fundo. E-mail: claudia.menoncini@gmail.com. ORCID: orcid.org/0000-0003-408901987.
} 


\section{Introduction}

The study of foreign ${ }^{1}$ languages has been in the spotlight for the last decades, at least since the spread of communicative teaching methodologies in the 1980s. Communicative approaches place the learner at the center of teaching and learning processes, and as a consequence, make educators rethink the design of lessons, how to act secondarily on stage and how to assess learners' performance and provide effective feedback, so that learning takes place.

Fast-paced technology, globalization, and the intense flow and multimodality of nowadays interactions have reallocated the position of English worldwide: from hegemonic models of standard pronunciation and accent to a globalized, international lingua franca (McKay, 2002; Rajagopalan, 2004; Seidlhofer, 2011; Jenkins, 2015). According to Seidlhofer (2011) and Jenkins (2015), a lingua franca is a hybrid type of language spoken by individuals with different first language backgrounds. English as a lingua franca democratizes the status of native and nonnative speakers, in a scenario where all adapt to each other's social and linguistic norms, creating novel forms of interaction through language.

Such a context poses challenges to the English for Specific Purposes (ESP) field. ESP might be one of the highest achievements of communicative foreign languages practices, since the starting point of such a methodology relies on the learners deciding what to study the language for. In a broad sense, ESP refers to communicational tasks learners undertake in their everyday routines and, as Holmes (2000) points out, should not be considered a separate discipline from other teaching methods, because the fact that it derives from needs analysis and is goal-oriented should work out as teaching principles for each and every language class, and not only for ESP-based ones.

Viana, Bocorny and Sarmento (2019, p. 03) state that ESP is usually related to one's profession or academic studies, and provide a subdivision to the term: English for Occupational Purposes (EOP) to the former and English for Academic Purposes (EAP) to the latter. Because it is not the goal of this paper to deepen theoretical terminology, nor to discuss the epistemological implications of adopting one term over the others (see Fn. \#1), the general term ESP is used (i) to map foreign language teaching in Medicine undergraduate courses in public universities in Brazil following the 2013 expansion plan of medical schools and the 2014 National Curricular Guidelines, and (ii) to present an ongoing proposal of ESP teaching in more detail in the context of the Federal University of Fronteira Sul, in Passo Fundo, RS.

The analysis to be provided is mainly fostered by one federal regulation to Medicine undergraduate courses in Brazil, that is, Diretrizes Curriculares Nacionais do Curso de Graduação em Medicina (Brasil, 2014) - hereafter the National Curricular Guidelines, which establish the necessity for proficiency of at least one foreign language, preferably a lingua franca (p. 04). Even though the document employs the term 'foreign language', it is assumed that English would be that foreign language, because it has long been the global means of 
communication in the academy, business and technology areas of scientific investigation.

Have medical undergraduate courses implemented the teaching of a lingua franca (English) by the time of the publication of the National Curricular Guidelines? This is the key question to be addressed by this paper, which is structured as follows (after this Introduction): section 1, Theoretical Framework; section 2, Methodology; section 3, Results and Discussion; section 4, ESP for medical students: a sample proposal; and section 5, Conclusion, followed by the References.

\section{Theoretical Framework}

Section 1.1 explains the principles and objectives of ESP. Section 1.2 describes the More Doctors Program (Programa Mais Médicos) and section 1.3 gives a detailed account of the National Curricular Guidelines (Diretrizes Curriculares Nacionais). The two last-mentioned sections account for a moment of great importance to the history of medical education in Brazil, and relate directly to the objectives of this study.

\subsection{English for Specific Purposes: a brief overview}

ESP originated at the end of World War II, in the same period of the audiolingual method, which was characterized by drilling, repetition and mechanical language practices focused on oral skills. Following the trends of that time, ESP was centered on form and on the detailed study of language in specific registers, that is, on the isolated teaching of grammar and specialized vocabulary. To Hutchinson and Waters (2010), its emergence is due to the economic development of the world and the consequent students' migration to English-speaking countries.

Discourse analysis has attempted to provide an answer to such a decontextualized approach to language, relating form to use, prioritizing the latter aspect rather than lexical and grammatical properties of register, and reinforcing text analysis. However, the gap at that time was the primary focus on language through texts and the neglect of the development of language skills. The following decades (1970s-1980s) were essential for establishing the fundamentals of ESP, particularly because of Hutchinson and Waters' influential works. These authors spread the concepts of 'need analyses' and 'learner-centered approach', believing that students should be led towards the development of an 'underlying competence' through the exploitation of acquired skills, which, in the long run, may drive them towards language learning autonomy.

Even with the basis grounded, it was not all a rose garden. Issues in the area concentrated on different views of ESP: one that advocated the teaching of English through topics beyond students' specialist areas, and another that focused on language practices on the students' specific areas of study. The discussion 
also reached the scope of skill specificity: do mono or several skills enhance language learning processes? Content and skills specificity, material design and the possibility of consulting an expert as an informant were a matter of debate at that time (Ramírez, 2015, p. 382).

When the scope of genre (Swales, 1990; Bhatia, 2002, to cite only a couple) reached the debate, discourse comes into play. In a discursive situation, several elements (including participants, their relationship, the context, their purposes, the mode of register, etc.) play a part in constituting the communicative situation, which primarily happens via genres. In the ESP approach, genre may help students analyze each situation carefully and apply pragmatic and linguistic strategies to perform successfully.

As stated by Hewings (2002), there has been an increasing number of ESP publications from other countries outside the US and the UK, which is in agreement with the contemporary notion of lingua franca presented in the Introduction. Additionally, the author observes that ESP approaches are recently more concentrated on genre and discourse analysis, proving that concurrent linguistic practices need to take into account target situations. In this direction, Hutchinson and Waters (2010) fostered the development the of ESP, expressing the importance of teaching students the skills and the language they need to achieve the desired performance in communication.

In Brazil, ESP was introduced in the late 1970s by means of a project entitled 'The Brazilian National ESP Project,' as a response to (i) the post-graduate qualification of university teachers, (ii) the little significance given to the area by language teachers, who taught that teaching the 'pure' language at Language Teaching Courses was a more noble task, and (iii) the increasing demands from other areas of science at universities for specialized English courses for students (Ramos, 2008).

ESP has been gradually shaped by the features of particular groups of learners, needs and goals, emphasizing the genre as the basis for discursive practices towards the accomplishment of specific purposes via language. As any language teaching approach, ESP has evolved following educational trends and national regulations in the medical field, as observed in the following sections 1.2 and 1.3.

\subsection{The More Doctors Program (O Programa Mais Médicos)}

The More Doctors Program was established in 2013 in order to prepare qualified human resources in the medical area to the Brazilian Unified Health System (Sistema Único de Saúde, SUS), aiming essentially at (i) reducing the lack of doctors in priority regions of the country, (ii) strengthening the services offered at primary healthcare, (iii) improving the general medical formation and (iv) reinforcing the association between public primary health services and higher education institutions (Brasil, 2013).

It is worth mentioning that the program implementation is a result of previous initiatives to expand medical education and services and to meet social demands: 'Phase 1 Expansion' in 2003, a movement towards the internationalization and the 
spread of federal higher education institutions and undergraduate courses; 'The Reuni Program' in 2007, as a continuation of the one proposed previously; and 'The PROVAB Program' in 2011, created to provide healthcare services to less accessible areas and with vulnerable populations (Oliveira et al., 2019). One cannot forget the Expansion Plan for Healthcare Education (Plano de Expansão da Educação em Saúde), established by way of the regulation 109/2012 (Brasil, 2012).

The More Doctors Program emerged to equate the proportion of physicians per inhabitant, which was 1.72/1000 in Brazil, considerably low when compared to developed countries such as Germany (3.53/1000) and Austria (4.74/1000), according to the World Health Statistics, published by the World Health Organization - WHO (2011) (as cited by Martins, Silveira \& Silvestre, 2013, p. 27). Despite the unequal distribution, there was a greater concentration of doctors in wealthier cities and in the state capitals, leaving marginalized populations unattended. The latest report available about the density of physicians per inhabitant sets out 2.14/1000 to Brazil (data from the year 2018), while Austria and Germany cover 5.14/1000 and 4.20/1000 respectively (data from the year 2016), as cited by the WHO website (https://www.who.int/gho/health workforce/ physicians_density/en/).

The Program has been recently replaced by a new program called 'Doctors for Brazil' (Médicos pelo Brasil), according to provisional measure 890, converted in law 13.958, from December 182019 (Brasil, 2019). Doctors for Brazil aims at incrementing medical services in high vulnerability places and at fomenting specialized medical formation in family and community medicine, in the scope of primary health care in the Unified Health System. As it had been with the More Doctors Program, it is expected that Doctors for Brazil provide equal health services to all populations and offer adequate fields of practice and education to training doctors, as enhanced by the National Curricular Guidelines for Medicine undergraduate courses in Brazil.

\subsection{The National Curricular Guidelines (Diretrizes Curriculares Nacionais)}

The National Curricular Guidelines (Brasil, 2014) is a resolution published by the Ministry of Education in June 2014, a revision of the document from 2001, and founds new curricular guidelines to Medicine undergraduate courses in Brazil. It applies to all medical courses operating for at least one year starting from the date of publication. Its three chapters cover (I) general guidelines - principles, foundations and objectives - to be followed in the structure, development and assessment of undergraduate medical courses in Brazil; (II) 'Areas of Competence', to which the guidelines must be applied (Healthcare, Healthcare Management and Healthcare Education); and (III) the essential curricular content required for Medicine courses and orientations on how to organize the pedagogical project.

Knowledge in foreign languages, the key point in discussion, is mentioned twice in the Guidelines (Brasil, 2014). In chapter 1 ('The Guidelines'), section III 
('Healthcare Education'), article 7, as one of the objectives regarding student's responsibility on his/her initial, continuing and in-service education:

To master a foreign language, preferably lingua franca, to keep updated with the national and international advances of Medicine, as well as to interact with other health teams in different parts of the world and to publish the scientific achievements from Brazil (p. 04).

Also, in chapter 3 ('Curricular Content and Pedagogical Project of the Medicine Undergraduate Course'), article 23, as one of the fundamental contents to be covered throughout the course: "comprehension and mastery of new communicational technology to access remote databases and the mastery of, at least, one foreign language, preferably a lingua franca" (p. 11).

The document is in line with the principles and goals of the More Doctors Program, as they both claim for a general, critical and socially-committed health education, fostering human citizenship and dignity along all the processes of healthcare. One of the strongest connections made in the documents is the alliance between health services and universities, allowing the concrete consolidation of theory and practice, academy and community. Historical and political tensions were and will still be part of the structure and implementation of proposals such as those, and should always be critically interpreted in order to best suit each particular context of healthcare promotion and education in the country. Due to the fact that foreign language learning is stated as both an objective and a fundamental content to be covered in Brazilian medical courses, it is clearly stated the need and relevance of developing teaching projects to suit each context's audience, demands and specific purposes. The Guidelines serve as a solid orientation to design foreign language teaching projects to foster the best in students, keeping in mind that they should be the center of the learning process.

\section{Methodology}

This is a bibliographical research. Data includes all public Medicine undergraduate courses in operation in Brazil. This list $(\mathrm{n}=121)$ was obtained in the e-MEC system (http://emec.mec.gov.br), a database for free public consultation, on 6 June 2019. By narrowing down the list to the number of courses created between 2013-2019, a final $n=43$ was reached.

The question pursued in this paper is: have medical undergraduate courses implemented the teaching of a lingua franca (English) by the publication of the National Curricular Guidelines? In order to get an answer and track more information about it, the following variables about the higher education institutions were controlled: (i) year of creation, (ii) type of higher education institution (federal, state, municipal), (iii) region in Brazil (the South, the Southeast, the Central-West, the North and the Northeast), (iv) course workload 
( $<8.000$ hours or $\geq 8.000$ hours), (v) foreign language included in the pedagogical project (English, any language, not mentioned) and (vi) status of the foreign language (curricular component, extracurricular activity, not mentioned). Withing this framework, the second objective is then to present an ongoing proposal of ESP teaching in more detail in the context of the Federal University of Fronteira Sul, in Passo Fundo, RS.

The data were taken from the PPPs and any other additional information needed to confirm these data was searched in the institutions' websites. This dataset was organized in a separate spreadsheet. Descriptive statistics was carried out to account for these set of data.

\section{Results and Discussion}

Out of the 43 selected public higher education institutions, 50\% were created in 2014, the same year of the publication of the National Curricular Guidelines; $25.6 \%$ were recently created but have not started their activities yet up to the moment of the consultation, neither have them made their pedagogical projects available on their official websites; and the remaining were distributed along the other years. The vast majority (74.4\%) are federal, $20.9 \%$ are state universities and only $4.7 \%$ are municipal. Most part of these universities are concentrated in the Northeast region of Brazil (39.5\%), followed by the Central-West (30.2\%) and the South (18.6\%). $48.8 \%$ of the medical pedagogical projects contain $<8.000$ hours and $51.2 \% \geq 8.000$ hours - that is, at a first glance, offering a lingua franca course in Medicine is not related to having more hours in the curriculum. $64.3 \%$ of the institutions state that any foreign language is accepted regards foreign language proficiency, $35.7 \%$ restrict this proficiency to English and 34.9\% do not include any foreign language in their pedagogical projects. When English is specified, $70 \%$ of the medical courses offer it as a curricular component, $10 \%$ accept it as extracurricular hours and the remaining $20 \%$ do not refer the status of the foreign language in the PPPs. The general picture of higher education institutions created since the expansion plan of medical schools in Brazil and the publication of the National Curricular Guidelines has the following predominant features:

Chart 1 - Predominant factors for each variable (general)

\begin{tabular}{ll} 
Variable & $>\%$ \\
\hline Year & 2014 \\
Type & federal \\
Region & Northeast \\
Foreign language & any \\
Status of foreign language in the PPP & not informed \\
\hline
\end{tabular}

The authors (2019). 
The boom on the implementation of Medicine undergraduate courses in 2014 is easily perceived, considering that was the year when the Guidelines were published, accompanied by the 2012 and 2013 expansion programs of medical schools. The federal character of the institutions is reflected by the government's educational policy, as well as its social concern with the development of less wealthy regions of the country, such as the Northeast, where most universities were implemented at that time. Despite the fact that a substantial amount of institutions state the necessity of the proficiency in a foreign language/lingua franca (65.1\%), the fact that they do not specify which language that is, nor inform about the status of such language in the curriculum, may represent, generally speaking, the secondary role that non-medical curricular components still occupy in Medical undergraduate courses, besides the possibility that information about foreign languages is only incorporated in the PPPs due to the existence of a resolution for that, relegating its real relevance for the full formation of upcoming doctors.

Taking into consideration only the $35.7 \%$ of universities that demand English proficiency from medical students, the snapshot obtained is that $80 \%$ are federal institutions, 50\% are located in the Northeast region, $40 \%$ in the South region and $10 \%$ in the Southeast. The workload of courses appears not to be an aspect of influence in offering English language programs: both factors $(<8.000$ hours and $\geq 8.000$ hours) apply the same (50\%) for all institutions. English is placed as a curricular component in $70 \%$ of these universities, as an extracurricular component in $10 \%$ of them and $20 \%$ of the institutions analyzed did not inform the status of the language. The general prevailing scenario for English in higher education institutions created since the expansion plan of medical schools in Brazil and the publication of the National Curricular Guidelines has the following features:

Chart 2 -Predominant factors for each variable (English)

\begin{tabular}{ll}
\hline Variable & $>\%$ \\
\hline Year & 2014 \\
Type & federal \\
Region & Northeast \\
Status of English in the PPP & curricular component \\
\hline
\end{tabular}

The authors (2019).

Given the broad overview of the situation - the implementation of any lingua franca in medical PPPs -, the answer to our research question is 'yes': a considerable number of Medicine undergraduate courses created between 20132019 refer a foreign language in their PPPs (65.1\%).

However, when considering the narrower scenario - the implementation of English as a lingua franca in the PPPs -, only $35.7 \%$ of Medicine undergraduate courses created between 2013-2019 indicate English as the lingua franca to be taught to students. Needless to say, these are data obtained by means of a bibliographical research. Whether any other project or program regarding ESP 
teaching is at work in the higher education institutions considered in this study is out of our reach.

\section{ESP for medical students: a sample proposal}

The Federal University of Fronteira Sul (UFFS) - Campus Passo Fundo is located in the city of Passo Fundo, in the north of Rio Grande do Sul, South of Brazil, and its main campus is in Chapecó, Santa Catarina, a neighbor state in the South of Brazil. UFFS Campus Passo Fundo was created in 2013 following the Expansion Plan for Healthcare Education (Plano de Expansão da Educação em Saúde), established by the Ministry of Education through regulation 109/2012 (Brasil, 2012).

This Medicine undergraduate course started its activities in 2013, counting on more than 300 medical students today, who come from the five regions of Brazil by means of the Unified Selection System, (SiSU, Sistema de Seleção Unificada). 62 vacancies are offered yearly. The pedagogical project of the course, which covers 8.715 hours, follows the principles of the Brazilian Federal Constitution as concerns the latest National Curricular Guidelines, the More Doctors Program, the Ministry of Education general guidelines and the healthcare policy of the Health Ministry, especially to what refers to the strengthening of the Unified Health System - SUS (UFFS, 2018).

In 2018, a language teaching program (Núcleo de Ensino de Línguas - NELI) was created and implemented in the stated campus via Resolution 02/2018 CONSEC-PF/UFFS/2018 (UFFS, 2018b), in order to work collaboratively with the Medicine undergraduate course coordination to design an English for Specific Purposes project for medical students, in accordance with what is established in the PPP and the referred legislation. In the future, NELI will also develop ESP projects to other undergraduate courses that might be offered in the Passo Fundo Campus.

At UFFS, medical students are called for to attest English proficiency level B1, according to the Common European Framework of Reference for Languages CEFR (Council of Europe, 2018), as a requirement to enter the medical internship, as established in the PPP (UFFS, 2018). All freshmen take a placement test every new semester and may (i) get the minimum proficiency straight ahead or (ii) take English Medical classes to develop such proficiency. They can also try other proficiency tests, as an extra option instead of taking lessons, such as the TOEFL itp or tests offered by higher education institutions.

The Medical English Program is structured into 6 curricular components, which correspond to the foreign language proficiency in the curriculum: Beginner 1 and 2 (level A1), Basic 1 and 2 (level A2) and Intermediate 1 and 2 (level B1), following the terminology and pedagogical orientations of the CEFR. All levels include language practices involving both oral and written skills and are focused on the development of academic and professional medical competences. Examples of such practices are reading and criticizing scientific articles, writing abstracts, listening to lectures from invited professors and asking questions or making points, roleplaying medical consultations and presenting and discussing 
clinical cases, all in English. English groups are mixed, with students from different semesters of the course.

NELI is part of a macro structure of a language development policy, in accordance with the Linguistic Policy (Política Linguística) of the Federal University of Fronteira Sul - Resolution 11/CONSUNI/UFFS/2018 (UFFS, 2018c) and the Languages Program (Programa de Linguas) (PROLIN) Resolution 06/CONSUNI/CPPGEC/UFFS 2019 (UFFS, 2019), whose purposes are to promote (i) a democratic access to language learning; (ii) the study of foreign languages and cultures, especially English, in order to foster internationalization and the insertion of the university in the scientific international context; and (iii) the linguistic proficiency of all sectors of the academic community.

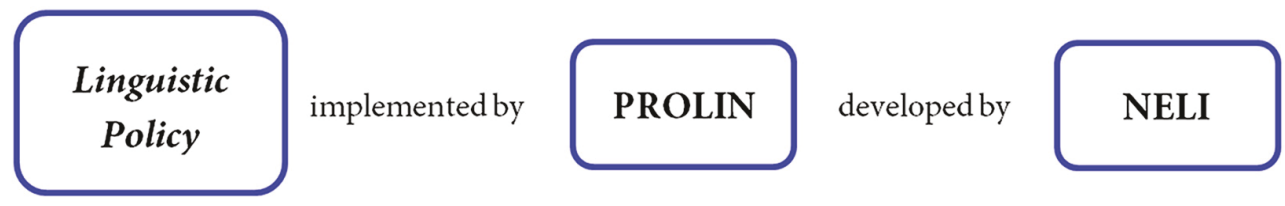

The authors (2019).

The proposal for medical students presented here is conforming with Hutchinson \& Waters' (2010) assumptions concerning the teaching of English for Specific Purposes, one that takes into account the necessary skills to develop particular competences, in language practices driven by both students' specialized area and beyond that as well. ESP today represents the consolidation of the demands expressed in the 1970s (Ramos, 2008), especially because of the impact that particular knowledge and skills in other areas than Letras has gained over the years. In terms of medical norms, ESP as exemplified here fulfils the objective of the lingua franca teaching, as proposed by official documents, and is implemented as one of the fundamental contents postulated by the Guidelines (Brasil, 2014) and the other government's medical educational programs (Brasil, 2012; 2013) and the specific language policies that direct it. Considering English a lingua franca and medical education focused on equity and social commitment, we are gradually promoting a more democratic, less elitist access to the English language learning and to medical education.

\section{Conclusion}

The More Doctors Program and the Brazilian National Curricular Guidelines come up with new principles and instructions to promote democratic medical education and services and to balance an existing unequal distribution and concentration of physicians along the regions of the country. This study has proved the impact of such regulations over medical education and services, evidenced by the expansion of Medical schools and the consequent broad coverage of doctors in marginal regions, for instance. A recent article published on the Lancet (Castro 
et al., 2019) restates the importance of establishing and maintaining the quality provision of healthcare services rapidly achieved (just three decades) in Brazil, without threatening its sustainability and "ability to fulfil its constitutional mandate of providing healthcare for all" (p. 345). Regarding ESP teaching, even though data, as we interpret it, have shown that there is still a generalized lack of concern with the teaching of English in Medicine undergraduate courses (only $35.7 \%$ of the institutions cover it), we have offered a representative case of implementation that works out effectively (a sequential program rather than one or two isolated English language disciplines) with the national healthcare and medical education regulations as well as updated pedagogical principles of ESP teaching and international foreign language guidelines. It is more than time to equalize the status and the conditions to offer high quality teaching of English and medical skills.

\section{Nota}

1. 'Foreign' is preferably employed to comply with the National Curricular Guidelines, and has no semantic difference from the terms 'additional,' 'second' or 'lingua franca'. The implications of adopting one term over others are not going to be addressed by this paper.

\section{References}

Bhatia, V. K. (2002). Applied genre analysis: a multiperspective model. Ibérica, 4, 3-19. Retrieved on July 252019 from http://www.aelfe.org/documents/text4Bhatia.pdf.

Brasil. (2012). Portaria $n^{o} 109$ de 05 de junho de 2012. Dispõe sobre a expansão de vagas... Retrieved on July 262019 from https://www.escolasmedicas.com.br/ news_det.php?cod $=1651$.

Brasil. (2013). Lei $n^{\circ} 12.871$ de 22 de outubro de 2013. Institui o Programa Mais Médicos... Retrieved on July 252019 from http://www.planalto.gov.br/ccivil_03/_ ato2011-2014/2013/Lei/L12871.htm.

Brasil. (2014). Diretrizes Curriculares Nacionais para o Curso de Graduação em Medicina. Retrieved on July 252019 from http://portal.mec.gov.br/ index.php?option $=$ com_docman\&view $=$ download $\&$ alias $=15874-$ rces00314\&category_slug=junho-2014-pdf\&Itemid $=30192$.

Brasil. (2019). Lei no 13.958 de 18 de dezembro de 2019. Institui o Programa Médicos pelo Brasil... Retrieved on January 132020 from http://www.planalto.gov.br/ ccivil_03/_ato2019-2022/2019/lei/L13958.htm.

Castro, M. C.; Massuda, A.; Almeida, G.; Menezes-Filho, N. A.; Andrade, M. V.; Noronha, K. V. M. S.; et al. (2019). Brazil's unified health system: the first 30 years and prospects to the future. The Lancet, 394, 10195, 345-356. Retrieved on July 302019 from https://www.thelancet.com/journals/lancet/article/PIIS01406736(19)31243-7/fulltext.

Council of Europe. (2018). Common European Framework of Reference for Languages: learning, teaching, assessment. Strasbourg, 2018. Retrieved on July 262019 from https://rm.coe.int/cefr-companion-volume-with-newdescriptors-2018/1680787989.

Hewings, M. (2002). A history of ESP through English for specific purposes. ESP-World, 1 (3). Retrieved on July 252019 from http://www.esp-world.info/ Articles_3/Hewings_paper.htm. 
Hutchinson, T.; Waters, A. (2010). English for Specific Purposes. A learner-centred approach. Cambridge: CUP. https://doi.org/10.1017/CBO9780511733031.

Holmes, J. (2000). What's my methodology? The ESP, 21, 127-146. Retrieved on July 252019 from https://revistas.pucsp.br/esp/article/download/9423/6994.

Jenkins, J. (2015). Repositioning English and Multilingualism in English as a Lingua Franca. English(es) in Practice, 2, 49-85. Retrieved on July 252019 from https:// pdfs.semanticscholar.org/9e9d/ace9e6b31e5397c4e77f6b39008f54ef83a1.pdf.

Martins, M. A.; Silveira, P. S. P.; Silvestre, D. (2013). Estudantes de Medicina e Médicos no Brasil: números atuais e projeções. São Paulo. Retrieved on July 252019 from http://www.fm.usp.br/cedem/conteudo/publicacoes/cedem_92_relatoriopaemi. pdf.

Mckay, S. L. (2002). Teaching English as an International Language. Oxford: OUP.

Oliveira, F. P.; Pinto, H. A.; Figueiredo, A. M.; Cyrino, E. G.; Oliveira Neto, A. V.; Rocha, V.X. M. (2019). Brazilian More Doctors Program: assessing the implementation of the Education Axis from 2013-2015. Interface, 23, 1-17. https://doi.org/10.1590/ Interface.170949.

Rajagopalan, K. (2004). The concept of "World English" and its implication for ELT. ELT Journal, 58, 111-117. Retrieved on July 252019 from https://www. deepdyve.com/lp/oxford-university-press/the-concept-of-world-english-andits-implications-for-elt-CdeGM5wP1G.

Ramírez, C. G. (2015). English for Specific Purposes: Brief History and Definitions. Revista de Lenguas Modernas, 23, 379-386. Retrieved on July 252019 from https:// pdfs.semanticscholar.org/3814/915d0982b11c86337c3f3f1 abcbf674fc4cb.pdf.

Ramos, R. C. G. (2008). ESP in Brazil: history, new trends and challenges. In Krzanowski, M. ESP and EAP in Developing and in Least Developing Countries. IATEFL, 68-83. Retrieved on July 252019 from http://www.teachingenglish.org. uk/sites/teacheng/files/ESPBrazil_Ramos_.pdf.

Seidlhofer, B. (2011). Understanding English as a Lingua Franca. Oxford: OUP.

Swales, J. M. (1990). Genre Analysis: English in Academic and Research Settings. New York: Cambridge University Press.

UFFS. (2018). Projeto Pedagógico do Curso de Graduação em Medicina. Passo Fundo, RS. Retrieved on July 262019 from https://www.uffs.edu.br/atos-normativos/ ppc/ccmpf/2018-0002/.../documento_historico.

UFFS. (2018b). RESOLUÇÃO No 02/2018 - CONSEC-PF/UFFS/2018. Institui o Núcleo de Ensino de Línguas do Campus Passo Fundo e aprova o Regimento do NELI. Retrieved on July 312019 from https://www.uffs.edu.br/campi/passofundo/nucleo-de-ensino-de-linguas/documentos.

UFFS. (2018c). RESOLUÇÃO No11/CONSUNI/UFFS/2018.Aprova a Política Linguística da Universidade Federal da Fronteira Sul (UFFS). Retrieved on July 312019 from https://www.uffs.edu.br/atos.../resolucao/consuni/2018-0011/.../ documento_historico.

UFFS. (2019). RESOLUÇÃO No 06/CONSUNI/CPPGEC/UFFS/2019. Institui o Programa de Línguas da Universidade Federal da Fronteira Sul. Retrieved on July 312019 from https://www.uffs.edu.br/atos.../resolucao/consunicppgec/2019.../ documento_historico.

Viana, V.; Bocorny, A.; Sarmento, S. (2019). Teaching English for Specific Purposes. Virginia/USA: TESOL Press. 